Article

\title{
Free radical mechanism investigation of the side-chain alkylation of toluene with methanol on basic zeolites $\mathrm{X}$
}

\author{
Huanhui Chen, Xiaoci Li, Guoqing Zhao, Hongbo Gu, Zhirong Zhu* \\ Department of Chemistry, Tongji University, Shanghai 200092, China
}

\section{A R T I C L E I N F O}

Article history:

Received 27 March 2015

Accepted 18 May 2015

Published 20 October 2015

\section{Keywords:}

Toluene

Side-chain alkylation

Radical mechanism

Zeolite X

Styrene

Isotope trace

\begin{abstract}
A B S T R A C T
The side-chain alkylation of toluene represents a novel, environmentally friendly, and low cost route for the production of styrene. However, the yield of styrene produced in this way is currently low, and the mechanism responsible for the side-chain alkylation of toluene is poorly understood. Furthermore, the reason for the higher catalytic efficiency of CsX over NaX and KX remains unclear. In this work, the free radical mechanism of the side-chain alkylation of toluene over basic zeolite $\mathrm{X}$ has been elucidated using quantum chemical calculations, together with isotope tracing experiments and the reaction between $p$-nitrotoluene and methanol. The adsorption isotherm of methanol showed that $\mathrm{Cs}^{+}$ions could block methanol from accessing the $\beta$-cage, which is where the side-chain alkylation reaction occurred. Furthermore, the H-D exchange results between toluene and deuterated toluene $\left(\mathrm{C}_{6} \mathrm{D}_{5} \mathrm{CD}_{3}\right)$ showed that $\mathrm{CsX}$ was more efficient as a catalyst than $\mathrm{KX}$ for the conversion of toluene to the corresponding benzyl radical $\left(\mathrm{C}_{6} \mathrm{H}_{5} \mathrm{CH}_{2}{ }^{\circ}\right)$. These two results therefore explain the higher catalytic activity of CsX towards side-chain alkylation than $\mathrm{KX}$. Based on the free radical mechanism, the selectivity of styrene could be increased from $17.4 \%$ to $59.4 \%$ using $\mathrm{CO}_{2}$ as carrier gas instead of $\mathrm{N}_{2}$.
\end{abstract}

(C) 2015, Dalian Institute of Chemical Physics, Chinese Academy of Sciences. Published by Elsevier B.V. All rights reserved.

\section{Introduction}

Styrene is an important material that is used for the production of a broad range of polymers, which are themselves used in numerous applications, including medical devices, toys, paper coatings and food packaging [1]. It is noteworthy that the annual worldwide consumption of styrene monomer is currently more than 30 million tons. However, there are many disadvantages associated with the traditional process for the production of styrene, including high costs, as well as high levels of energy consumption and environmental pollution resulting from the high reaction temperature and toxic nature of the raw materials [2]. To address these issues, there has been a recent increase in research directed towards the side-chain alkylation of toluene because it has the potential to provide a novel route for the production of styrene while avoiding the limitations associated with the traditional production process [3-11].

Yashima et al. [1] and Sidorenko et al. [12] reported that the catalytic activities of X-type zeolites for the side-chain alkylation of toluene with methanol was higher than those of Y-type zeolites. Freeman et al. [13] reported that the catalytic efficiencies of several X-type zeolites increased with the increasing size of the alkali-metal cations used in their reactions (i.e., $\mathrm{NaX}<\mathrm{KX}$ $<\mathrm{CsX}$ ). However, the precise reason for the higher catalytic efficiency of CsX compared with $\mathrm{NaX}$ and $\mathrm{KX}$ remains unclear. Furthermore, the mechanism of the side-chain alkylation of toluene is poorly understood. Rep [14] postulated a mechanism for the side-chain alkylation of toluene. According to this

\footnotetext{
* Corresponding author. Tel: +86-21-65982563; Fax: +86-21-65982563; E-mail: zhuzhirong@tongji.edu.cn This work was supported by the National Natural Science Foundation of China (51174277) and Shanghai Key Basic Research (11JC1412500). DOI: 10.1016/S1872-2067(15)60896-8 | http://www.sciencedirect.com/science/journal/18722067 | Chin. J. Catal., Vol. 36, No. 10, October 2015
} 
mechanism, methanol would be initially dehydrogenated to give formaldehyde (Eq. (1)), which would react with toluene to form styrene via an aldol-type condensation reaction (Eq. (2)). The styrene would then be reduced to ethylbenzene (Eq. (3)).

$$
\begin{aligned}
& \mathrm{CH}_{3} \mathrm{OH} \rightarrow \mathrm{H}_{2} \mathrm{CO}+\mathrm{H}_{2}
\end{aligned}
$$

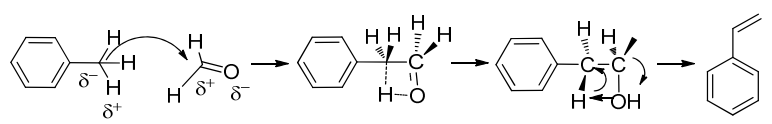

$$
\begin{aligned}
& \mathrm{C}_{6} \mathrm{H}_{5} \mathrm{CH}=\mathrm{CH}_{2}+\mathrm{H}_{2} \rightarrow \mathrm{C}_{6} \mathrm{H}_{5} \mathrm{CH}_{2} \mathrm{CH}_{3}
\end{aligned}
$$

However, the dehydrogenation of methanol on $\mathrm{NaCO}_{3}$ [15] and the cracking reaction of propylbenzene to toluene $[16,17]$ is generally considered to proceed via a free radical mechanism, suggesting the possibility that a free radical mechanism could be responsible for the formation of styrene during the side-chain alkylation of toluene. Spin trapping-electron spin resonance (ESR) experiments are normally used to determine whether a reaction proceeds via a radical mechanism. Unfortunately, this technique cannot be used in this particular case because the side-chain alkylation of toluene is conducted at high temperatures (ca. $420^{\circ} \mathrm{C}$ ), which are too high to use a radical trapping reagent.

With this in mind, isotope tracing experiments have been used in the current study together with the reaction between $p$-nitrotoluene and methanol to confirm the free radical mechanism of the side-chain alkylation of toluene over basic zeolite $\mathrm{X}$. The higher catalytic activity of CsX towards the side-chain alkylation compared with $\mathrm{KX}$ has been explained in terms of the adsorption isotherm of methanol and H-D exchange experiments between toluene and deuterated toluene $\left(\mathrm{C}_{6} \mathrm{D}_{5} \mathrm{CD}_{3}\right)$. The use of $\mathrm{CO}_{2}$ as carrier gas instead of $\mathrm{N}_{2}$ led to an increase in the selectivity for styrene.

\section{Experimental}

\subsection{Materials preparation}

$\mathrm{NaX}$ zeolite was obtained from Tong Xing Corp (Shanghai, China). The CsX and KX zeolites were prepared from NaX following three ion exchange processes with aqueous solutions (1 $\mathrm{mol} / \mathrm{L}$ ) of $\mathrm{CsOH}$ and $\mathrm{KOH}$, respectively. The exchanged samples were dried at $85^{\circ} \mathrm{C}$ and calcined in air at $520^{\circ} \mathrm{C}$ for $3 \mathrm{~h}$ before being rehydrated and rinsed with distilled water. Deuterated methanol- $\mathrm{d}_{4}\left(\mathrm{CD}_{3} \mathrm{OD}\right)$ and deuterated toluene- $\mathrm{d}_{8}\left(\mathrm{C}_{6} \mathrm{D}_{5} \mathrm{CD}_{3}\right)$ were provided by Aladdin Industrial Corporation (Shanghai, China).

\subsection{Catalytic reaction}

\subsubsection{Isotope trace experiments}

A specific amount of each catalyst was packed into stainless steel tubular fixed-bed reactors with an inner diameter of 1.5 $\mathrm{cm}$. A mixture of toluene and deuterated methanol- $\mathrm{d}_{4}$ was then pumped into the reactors at a rate of $10 \mathrm{~mL} / \mathrm{h}$. The isotope tracing side-chain alkylation reactions were carried out at 425 ${ }^{\circ} \mathrm{C}$ using a 10:1 (mol/mol) mixture of toluene and $\mathrm{CD}_{3} \mathrm{OD}$ under atmospheric pressure with $\mathrm{N}_{2} 30 \mathrm{~mL} / \mathrm{min}$.

\subsubsection{P-nitrotoluene side-chain alkylation}

CsX catalyst ( $5.0 \mathrm{~g}$ ) was packed into a stainless steel tubular fixed-bed reactor with $1.5 \mathrm{~cm}$ inner diameter. The reactants were pumped into the reactor at a rate of $10 \mathrm{~mL} / \mathrm{h}$. Side-chain alkylation was carried out at $425{ }^{\circ} \mathrm{C}, 1: 1: 20$-nitrotoluene: methanol: benzene molar ratio, and atmospheric pressure with $\mathrm{N}_{2} 30 \mathrm{~mL} / \mathrm{min}$.

\subsubsection{H/D exchange experiments}

The catalyst (active carbon, $\mathrm{CsX}$, or $\mathrm{KX}$ ) was packed into a stainless steel tubular fixed-bed reactor with $1.5 \mathrm{~cm}$ inner diameter. The mixture of toluene and toluene-d 8 was pumped into the reactor, giving a feed rate (WHSV) of $2 \mathrm{~g} \mathrm{~g}^{-1} \mathrm{~h}^{-1}$. Side-chain alkylation was carried out at $380{ }^{\circ} \mathrm{C}, 1: 10$ toluene: toluene- $\mathrm{d}_{8}$ molar ratio, and atmospheric pressure with $\mathrm{N}_{2} 30$ $\mathrm{mL} / \mathrm{min}$.

\subsection{4. $\mathrm{CO}_{2}$ effect experiments}

CsX catalyst ( $5.0 \mathrm{~g}$ ) was packed into a stainless steel tubular fixed-bed reactor with $1.5 \mathrm{~cm}$ inner diameter. The mixture of toluene and methanol was pumped into the reactor at a rate of $10 \mathrm{~mL} / \mathrm{h}$. Side-chain alkylation was carried out at $420{ }^{\circ} \mathrm{C}, 1: 1$ toluene: methanol molar ratio, atmospheric pressure with $\mathrm{CO}_{2}$ (N2) $30 \mathrm{ml} / \mathrm{min}$.

\section{Results and discussion}

\subsection{Mechanism verification}

The mechanism of the side-chain alkylation of toluene was initially investigated using $\mathrm{CD}_{3} \mathrm{OD}$ as an isotope tracer. The crude product was analyzed by GC-MS and ${ }^{2} \mathrm{H}-\mathrm{NMR}$. The ${ }^{2} \mathrm{H}-\mathrm{NMR}$ spectrum of the reaction mixture (Fig. 1(a)) contained peaks at 2.23 and $1.18 \mathrm{ppm}$, which were assigned to the deuterated methyl groups of toluene and ethylbenzene, respectively.

Notably, the ion mechanism postulated by Marco Rep (as shown in Eqs. (1-3)) could not be used to explain why most of $\mathrm{D}$ atoms were located on toluene, whereas very few were attached to the $\beta$-C atoms of ethylbenzene. According to Eqs. (1-3), the $\beta$-C atoms of the styrene and ethylbenzene products resulting from the ion mechanism should contain deuterium. However, the results showed that only a small amount of D was incorporated on to the $\beta$-C atoms of ethylbenzene and that most of $\mathrm{D}$ were observed on the toluene. This result therefore suggested that the H-D exchange reaction between the methyl groups of $\mathrm{CD}_{3} \mathrm{OD}$ and toluene was occurring by a free radical reaction (Eqs. (4-7)).

$$
\begin{aligned}
& \mathrm{C}_{6} \mathrm{H}_{5} \mathrm{CH}_{3} \rightleftarrows \mathrm{C}_{6} \mathrm{H}_{5} \mathrm{CH}_{2} \bullet+\mathrm{H}^{\bullet} \\
& \mathrm{CD}_{3} \mathrm{OD} \rightleftarrows \cdot \mathrm{CD}_{2} \mathrm{OD}+\mathrm{D} \cdot \\
& \mathrm{C}_{6} \mathrm{H}_{5} \mathrm{CH}_{2} \bullet+\mathrm{D} \bullet \mathrm{C}_{6} \mathrm{H}_{5} \mathrm{CH}_{2} \mathrm{D} \\
& \cdot \mathrm{CD}_{2} \mathrm{OD}+\mathrm{H} \bullet \rightleftarrows \mathrm{CHD}_{2} \mathrm{OD}
\end{aligned}
$$

As indicated in the above equations, the toluene would be cracked to give $\mathrm{C}_{6} \mathrm{H}_{5} \mathrm{CH}_{2} \cdot$ and $\mathrm{H}^{\bullet}$ and $\mathrm{CD}_{3} \mathrm{OD}$ would dissociate to give ${ }^{\bullet} \mathrm{CD}_{2} \mathrm{OD}$ and a deuterium radical (D•). The $\mathrm{C}_{6} \mathrm{H}_{5} \mathrm{CH}_{2} \bullet$ and $\mathrm{D}^{\bullet}$ radicals would then combine to form deuterated toluene- $\mathrm{d}_{1}$ $\left(\mathrm{C}_{6} \mathrm{H}_{5} \mathrm{CH}_{2} \mathrm{D}\right)$, whilst ${ }^{\circ} \mathrm{CD}_{2} \mathrm{OD}$ would react with $\mathrm{H} \cdot$ to give trideu- 
(a)

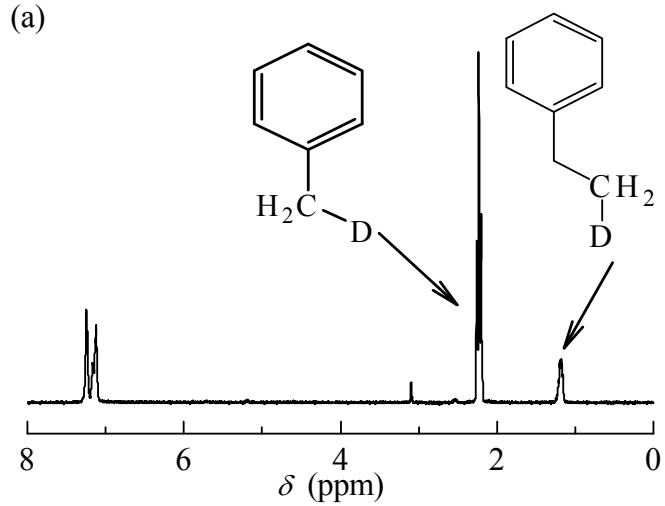

(c)

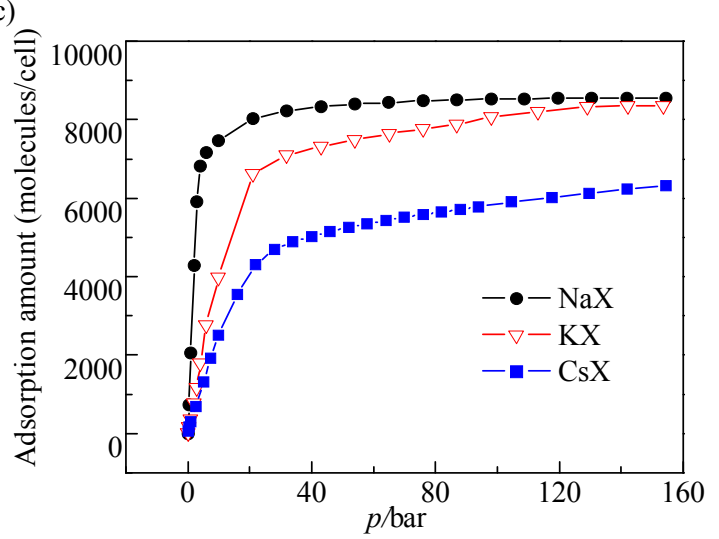

(b)

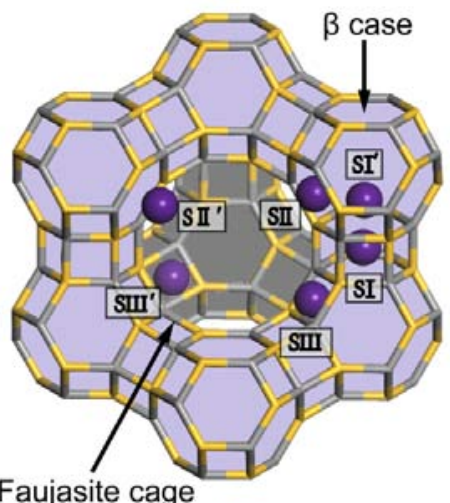

(d)

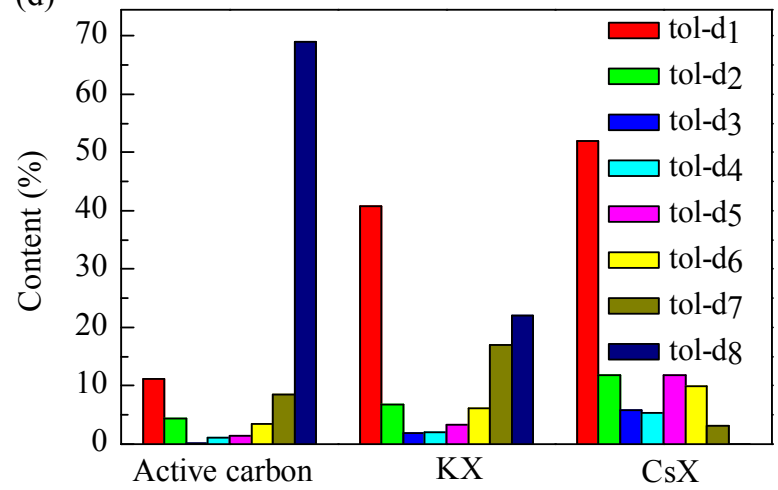

Fig. 1. (a) 'H-NMR spectrum of the reaction mixture; (b) Representation of the faujasite structure showing only the tetrahedral atoms (SI, SI', SII, SII', SIII, and SIII' are the positions of the cationic sites); (c) Adsorption isotherms of methanol; (d) Deuterium distribution density.

teromethanol $\left(\mathrm{CHD}_{2} \mathrm{OD}\right)$.

Seemingly, $\mathrm{H}-\mathrm{D}$ exchange between methyl group of $\mathrm{CD}_{3} \mathrm{OD}$ and toluene also could proceed by ion reaction (Eqs. (8-11)).

$$
\begin{aligned}
\mathrm{C}_{6} \mathrm{H}_{5} \mathrm{CH}_{3} & \rightleftarrows \mathrm{C}_{6} \mathrm{H}_{5} \mathrm{CH}_{2}+\mathrm{H}^{+} \\
\mathrm{CD}_{3} \mathrm{OD} & \rightleftarrows \mathrm{CD}_{2} \mathrm{OD}^{-}+\mathrm{D}^{+} \\
\mathrm{C}_{6} \mathrm{H}_{5} \mathrm{CH}_{2}+\mathrm{D}^{+} & \rightleftarrows \mathrm{C}_{6} \mathrm{H}_{5} \mathrm{CH}_{2} \mathrm{D} \\
\mathrm{CD}_{2} \mathrm{OD}^{-}+\mathrm{H}^{+} & \rightleftarrows \mathrm{CHD}_{2} \mathrm{OD}
\end{aligned}
$$

Quantum chemical calculations were performed at the B3LYP/6-31+G level using the Gaussian 09 program system to verify the route of the H-D exchange reaction. Scheme 1 provides a visual insight into the energies associated with the different reactants, as well as the energies of the transition states and products. The transition state of the radical mechanism was found to be about 0.149 Hartree higher than that of methanol. In contrast, the transitions state of the ion mechanism was about 0.657 Hartree. The energy barrier associated with the radical route was therefore shown to be much lower than that of the ion route, which provided a strong indication that the $\mathrm{H}-\mathrm{D}$ exchange reaction between the methyl group of $\mathrm{CD}_{3} \mathrm{OD}$ and toluene would have proceeded via the radical route.

Although the results of the $\mathrm{H}-\mathrm{D}$ exchange reaction can be used to confirm the presence of free radicals during the reaction, they cannot be used to demonstrate that the side-chain alkylation of toluene proceeds via a free radical reaction. To examine whether the side-chain alkylation of toluene is a free radical reaction, we investigated the reaction of $p$-nitrotoluene $\left(\mathrm{NO}_{2}-\mathrm{Ph}-\mathrm{CH}_{3}\right)$ with methanol instead of toluene. Aromatic nitro-groups generally behave as strong electron acceptors, as evidenced by the fact that the methyl hydrogen of $\mathrm{NO}_{2}-\mathrm{Ph}-\mathrm{CH}_{3}$ $\left(\mathrm{p} K_{\mathrm{a}}=20.4\right.$ ) dissociates much more readily to give $\mathrm{H}^{+}$than that of toluene $\left(\mathrm{p} K_{\mathrm{a}}=43\right)$, with the resulting $p$-nitro-benzyl anion $\left(\mathrm{NO}_{2}-\mathrm{Ph}-\mathrm{CH}_{2}{ }^{-}\right)$being much more stable than the benzyl anion $\left(\mathrm{Ph}^{-} \mathrm{CH}_{2}{ }^{-}\right)$. If the side-chain alkylation of toluene did proceed via an ionic mechanism, then the yield of the product resulting from the side-chain alkylation of $p$-nitrotoluene would increase compared with that of toluene. Furthermore, nitrobenzene compounds generally behave as radical free radical scavenger because aromatic nitro groups can react with active radicals to form more stable radicals (Eq. (12)).

$$
\mathrm{R} \cdot+\mathrm{Ar}-\mathrm{NO}_{2} \longrightarrow \mathrm{Ar}-\mathrm{N}^{\prime \prime}-\mathrm{O}-\mathrm{R}
$$

However, if the side-chain alkylation did proceed via a free radical reaction mechanism, then the methyl side-chain of $p$-nitrotoluene would not be alkylated. In practice, the results of this experiment revealed that there was no product resulting from the side-chain alkylation of $p$-nitrotoluene, which indicated that the side-chain alkylation of toluene proceeded via a free radical reaction.

Overall, the isotope trace experiments demonstrated that a $\mathrm{D}$ atom from the methyl group of $\mathrm{CD}_{3} \mathrm{OD}$ was exchanged with a hydrogen atom from the methyl group of toluene. Furthermore, the results of the quantum chemical calculations showed that the energy barrier for the H-D exchange reaction was 0.148640 Hartree for the radical route and 0.656555 Hartree for the ionic route. Taken together, these results provided strong evidence in support of the H-D exchange reaction between the methyl 

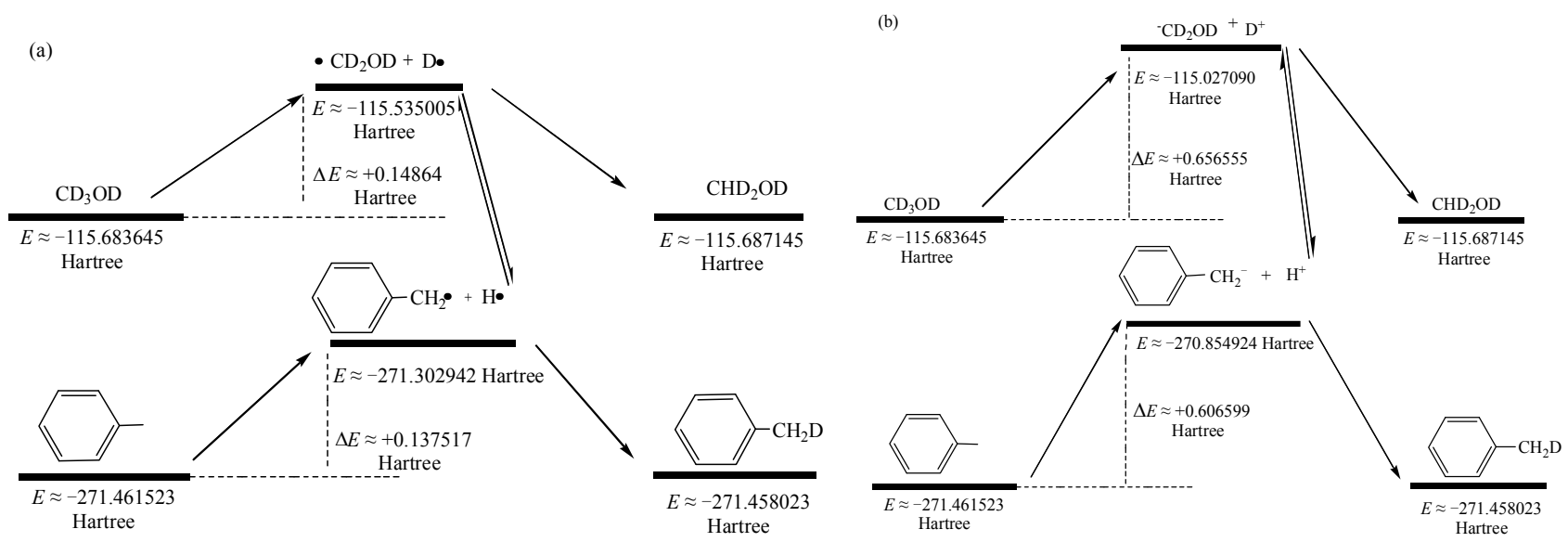

Scheme 1. (a) Relative energies of H/D exchange between toluene and methanol (Hartree) in radical mechanism; (b) Relative energies of H/D exchange between toluene and methanol (Hartree) in radical mechanism.

groups of $\mathrm{CD}_{3} \mathrm{OD}$ and toluene proceeding via a radical mechanism. Further proof of this process occurring via a radical mechanism came from the observation that the side chain of $p$-nitrotoluene was not alkylated with methanol. Instead, the $\mathrm{C}_{6} \mathrm{H}_{5} \mathrm{CH}_{3} / \mathrm{C}_{6} \mathrm{H}_{5} \mathrm{CH}_{2} \cdot$ reacted with $\mathrm{CH}_{3} \cdot / \mathrm{CH}_{3} \mathrm{OH}$ to generate 2-phenyl-ethanol $\left(\mathrm{C}_{6} \mathrm{H}_{5} \mathrm{CH}_{2} \mathrm{CH}_{2} \mathrm{OH}\right)$, which underwent a dehydration to produce styrene (Eqs. (13) and (14)). Furthermore, the reaction of $\mathrm{C}_{6} \mathrm{H}_{5} \mathrm{CH}_{2}{ }^{\bullet}$ with $\mathrm{CH}_{3} \mathrm{OH}$ and the reaction of $\mathrm{CH}_{3}{ }^{*}$ with $\mathrm{C}_{6} \mathrm{H}_{5} \mathrm{CH}_{3}$ would give ethylbenzene (Eqs. (15) and (16)). Ethylbenzene was also produced by the hydrogenation of styrene with $\mathrm{H} \cdot$ (Eq. (17)).

$$
\begin{aligned}
& \mathrm{C}_{6} \mathrm{H}_{5} \mathrm{CH}_{2} \cdot+\mathrm{CH}_{3} \mathrm{OH} \stackrel{-\mathrm{H}^{-}}{\rightleftharpoons} \mathrm{C}_{6} \mathrm{H}_{5} \mathrm{CH}_{3} \mathrm{CH}_{2} \mathrm{OH} \rightleftarrows \mathrm{C}_{6} \mathrm{H}_{5} \mathrm{CH}=\mathrm{CH}_{2} \\
& \mathrm{C}_{6} \mathrm{H}_{5} \mathrm{CH}_{3}+{ }^{\cdot} \mathrm{CH}_{2} \mathrm{OH} \stackrel{-\mathrm{H}^{-}}{\rightleftharpoons} \mathrm{C}_{6} \mathrm{H}_{5} \mathrm{CH}_{3} \mathrm{CH}_{2} \mathrm{OH} \rightleftarrows \mathrm{C}_{6} \mathrm{H}_{5} \mathrm{CH}=\mathrm{CH}_{2} \\
& \mathrm{C}_{6} \mathrm{H}_{5} \mathrm{CH}_{2} \cdot+\mathrm{CH}_{3} \mathrm{OH} \stackrel{-\mathrm{HO}^{-}}{=} \mathrm{C}_{6} \mathrm{H}_{5} \mathrm{CH}_{2} \mathrm{CH}_{3} \\
& \mathrm{C}_{6} \mathrm{H}_{5} \mathrm{CH}_{3}+\mathrm{CH}_{3} \cdot \stackrel{-\mathrm{H}^{-}}{\longrightarrow} \mathrm{C}_{6} \mathrm{H}_{5} \mathrm{CH}_{2} \mathrm{CH}_{3} \quad \Delta H=50.6 \mathrm{~kJ} / \mathrm{mol} \\
& \mathrm{C}_{6} \mathrm{H}_{5} \mathrm{CH}=\mathrm{CH}_{2}+2 \mathrm{H} \cdot \rightleftarrows \mathrm{C}_{6} \mathrm{H}_{5} \mathrm{CH}_{2} \mathrm{CH}_{3} \\
& \mathrm{CH}_{3} \mathrm{OH}+\mathrm{H} \bullet \rightleftarrows \mathrm{CH}_{3} \cdot+\mathrm{H}_{2} \mathrm{O} \\
& \mathrm{CH}_{3} \mathrm{OH}+\mathrm{H} \cdot \rightleftarrows \mathrm{H}_{2}+\cdot \mathrm{CH}_{2} \mathrm{OH}
\end{aligned}
$$

Toluene could also react with $\mathrm{CH}_{3} \cdot$ to generate ethylbenzene (Eq. (16)), and the $\mathrm{CH}_{3} \cdot$ radical could react with $\mathrm{CH}_{3} \mathrm{OH}$ to generate $\mathrm{CH}_{4}$ (Eq. (20)), CO (Eq. (21)), and several other by-products. The radical mechanism could also be used to explain the formation of $\mathrm{CO}$ and $\mathrm{CH}_{4}$ (Eqs. (20) and (21)). The enthalpy changes associated with Eqs. (16), (20), and (21) were $50.6,-27.9$, and $-27.0 \mathrm{~kJ} / \mathrm{mol}$, respectively, and therefore very different. Based on the theory of thermodynamics, $\mathrm{CH}_{3} \cdot$ would be better suited to form $\mathrm{CH}_{4}$ and $\mathrm{CO}$ than styrene and ethylbenzene. To improve the usage of $\mathrm{CH}_{3} \mathrm{OH}$, it would therefore be necessary to reduce the probability of a collision between $\mathrm{CH}_{3} \cdot$ and $\mathrm{CH}_{3} \mathrm{OH}$ /formaldehyde $\left(\mathrm{CH}_{2} \mathrm{O}\right)$, while improving the probability of a collision between $\mathrm{CH}_{3} \cdot$ and $\mathrm{C}_{6} \mathrm{H}_{5} \mathrm{CH}_{3}$ (or $\mathrm{C}_{6} \mathrm{H}_{5} \mathrm{CH}_{2} \cdot$ ).

$$
\begin{aligned}
& \mathrm{CH}_{3} \cdot+\mathrm{CH}_{3} \mathrm{OH} \rightleftarrows \mathrm{CH}_{4}+\cdot \mathrm{CH}_{2} \mathrm{OH} \quad \Delta H=-37.9 \mathrm{~kJ} / \mathrm{mol} \\
& \mathrm{CH}_{3} \cdot+\mathrm{CH}_{2} \mathrm{O} \rightleftarrows \mathrm{CH}_{4}+\mathrm{CO}+\mathrm{H}^{\bullet} \quad \Delta H=-27.0 \mathrm{~kJ} / \mathrm{mol}
\end{aligned}
$$

\section{2. $\beta$ cages constraint on methanol}

X-type zeolites are composed of faujasite and $\beta$ cages (Fig. 1(b)). The diameters of the 12- and 6-ring orifices of the faujasite and $\beta$ cage structures are around 0.74 and $0.25 \mathrm{~nm}$, respectively. The diameter of toluene is about $0.65 \mathrm{~nm}$, which is much bigger than the diameter of the 6 -ring orifice of the $\beta$ cage structure of the NaX. With this in mind, toluene should be able go inside the faujasite cages, but not inside the $\beta$ cages. Basler et al. [18] demonstrated that $\mathrm{NH}_{3}$ can enter the $\beta$ cages of $\mathrm{NaX}$. Given that the diameter of $\mathrm{CH}_{3} \mathrm{OH}$ is similar to that of $\mathrm{NH}_{3}$, it was envisaged that $\mathrm{CH}_{3} \mathrm{OH}$ would also be able to access to the $\beta$ cages of NaX.

The adsorption isotherms of $\mathrm{CH}_{3} \mathrm{OH}$ were measured to determine the validity of this hypothesis and the results are shown in Fig. 1(c). The results revealed that $\mathrm{NaX}$ had a similar adsorption capacity (ca. 8500 molecules per unit cell) to KX. The adsorption capacity of $\mathrm{NaX}$ was found to be much greater than that of CsX (ca. 6300 molecules per unit cell). This result indicated that the $\beta$ cages would be blocked when SII and SII' were occupied by $\mathrm{Cs}^{+}$instead of $\mathrm{K}^{+}$because the radius of $\mathrm{Cs}^{+}$is larger than that of $\mathrm{K}^{+}$and $\mathrm{CH}_{3} \mathrm{OH}$ would therefore be prevented from entering the $\beta$ cages. In this case, the $\mathrm{CH}_{3} \cdot$ radical would only be able to react with $\mathrm{CH}_{3} \mathrm{OH} / \mathrm{CH}_{2} \mathrm{O}$ to form side-products in the $\beta$ cages. Furthermore, the $\mathrm{CH}_{3}{ }^{\bullet}$ radicals would collide with toluene molecules to generate styrene and ethylbenzene in the faujasite cages. The blocking of the $\beta$ cages with $\mathrm{Cs}^{+}$ions would therefore improve the probability of collisions between the $\mathrm{CH}_{3} \cdot$ radicals and toluene (or $\mathrm{C}_{6} \mathrm{H}_{5} \mathrm{CH}_{2}{ }^{\circ}$ ). Taken together, these results show that $\mathrm{CsX}$ is more efficient than $\mathrm{KX}$ for catalyzing the reaction of $\mathrm{CH}_{3} \mathrm{OH}$ with toluene to give styrene and ethylbenzene.

\subsection{Activation ability of toluene on different $X$ zeolites}

As mentioned above, the side-chain alkylation of toluene occurs via a free radical mechanism. With this in mind, the process responsible for the formation of the free radicals represents an important step in this reaction. The activation of $\mathrm{C}_{6} \mathrm{H}_{5} \mathrm{CH}_{3}$ to give the corresponding radical species $\mathrm{C}_{6} \mathrm{H}_{5} \mathrm{CH}_{2}$. was evaluated with a variety of different catalysts based on the $\mathrm{H} / \mathrm{D}$ exchange reaction of a 10:1 (mol/mol) mixture of $\mathrm{C}_{6} \mathrm{H}_{5} \mathrm{CH}_{3}$ and $\mathrm{C}_{6} \mathrm{D}_{5} \mathrm{CD}_{3}$. The resulting distribution of $\mathrm{D}$ in the products 
was analyzed by GC-MAS and the results are shown in Fig. 1(d).

The deuterium distribution density results (Fig. 1(d)) showed that $\mathrm{C}_{6} \mathrm{D}_{5} \mathrm{CD}_{3}$ existed as the major species in the reaction mixture when the catalytic process was conducted with active carbon. This result indicated that it was difficult to convert $\mathrm{C}_{6} \mathrm{H}_{5} \mathrm{CH}_{3}$ to the corresponding $\mathrm{C}_{6} \mathrm{H}_{5} \mathrm{CH}_{2} \cdot$ radical using activated carbon as a catalyst. Furthermore, the experiments involving the side-chain alkylation of toluene showed that the conversion of toluene was about $0.1 \%$ when the reaction was conducted over active carbon (Table 1). Taken together, these results show that the catalytic effect of activated carbon towards the side-chain alkylation of $\mathrm{C}_{6} \mathrm{H}_{5} \mathrm{CH}_{3}$ was in agreement its catalytic effect towards the conversion of $\mathrm{C}_{6} \mathrm{H}_{5} \mathrm{CH}_{3}$ to $\mathrm{C}_{6} \mathrm{H}_{5} \mathrm{CH}_{2} \cdot$. In contrast, when the reaction was conducted in the presence of a X-type zeolite (KX or CsX), the amount of $\mathrm{C}_{6} \mathrm{D}_{5} \mathrm{CD}_{3}$ decreased sharply, whereas the amount deuterated toluene- $\mathrm{d}_{1}$ increased considerably. This result demonstrates that the zeolite was having a significant effect on activating toluene towards free radicals. The effect of the zeolite could be attributed to a captodative effect involving the synergistic effect of electron-withdrawing (captor) and electron-releasing (donor) groups attached to the radical center, which could make the radical much more stable [19]. As the toluene molecules entered the cavities of the zeolite, the cations would form complexes with the aromatic rings, and the resulting complexes would attract electrons. At the same time, the anions within the zeolite framework would donate an electron to the methyl group of toluene (Fig. 2). Based on these interactions, the zeolite would be able to stabilize the $\mathrm{C}_{6} \mathrm{H}_{5} \mathrm{CH}_{2} \cdot$ radical.

Compared with the $\mathrm{KX}$ catalyst, more of the deuterium atoms present in the mixture existed as toluene- $\mathrm{d}_{1}$ following the CsX-catalyzed process. The fact that more deuterium atoms were exchanged from deuterated toluene to toluene using the CsX catalyst demonstrated that the H/D exchange process occurred to a much greater extent over the CsX catalyst than it did over the $\mathrm{KX}$ catalyst and that the $\mathrm{C}_{6} \mathrm{H}_{5} \mathrm{CH}_{2} \bullet$ radical was much more stable over CsX. Cs can lose an electron more readily than $\mathrm{K}$, which means that the $\mathrm{CsX}$ zeolite has a weaker $\mathrm{Cs}^{+}$cation (electron-withdrawing) and stronger framework anion (electron-releasing) than the $\mathrm{KX}$ zeolite. The cooperativity of the acceptor and donor moieties of the CsX zeolite therefore possesses better captodative effects to increase the stability of the $\mathrm{C}_{6} \mathrm{H}_{5} \mathrm{CH}_{2} \cdot$ radical. Furthermore, $\mathrm{CsX}$ exhibited higher catalytic activity towards the side-chain alkylation of toluene than $\mathrm{KX}$. The levels of toluene conversion using the CsX and $\mathrm{KX}$ zeolites were found to be $16.6 \%$ and $3.6 \%$ (Table 1), respectively. This result therefore demonstrates that the higher catalytic activity

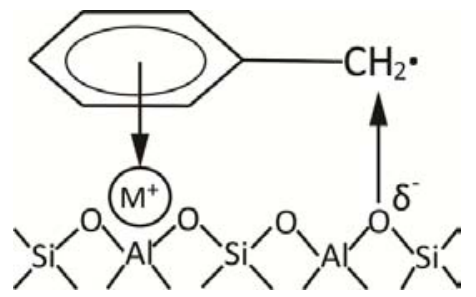

Fig. 2. The captodative effect of metal cation and anion on the framework.

of CsX towards the conversion of $\mathrm{C}_{6} \mathrm{H}_{5} \mathrm{CH}_{3}$ to $\mathrm{C}_{6} \mathrm{H}_{5} \mathrm{CH}_{2} \cdot$ was critical to its higher catalytic activity towards the side-chain alkylation of toluene compared with KX.

\section{4. $\mathrm{CO}_{2}$ effect on the selectivity of styrene}

Several experiments were designed to improve the selectivity of the side-chain alkylation reaction of toluene based on the radical reaction mechanism. Notably, $\mathrm{CO}_{2}$ was used as a carrier gas instead of $\mathrm{N}_{2}$. Under an atmosphere of $\mathrm{N}_{2}$, there are three possible reaction routes for $\mathrm{H}^{\bullet}$ (Fig. 3(a)), including: (1) the reaction of $\mathrm{H}^{\bullet}$ with $\mathrm{CH}_{3} \mathrm{OH}$ following route $\mathrm{S}$ to generate $\cdot \mathrm{CH}_{2} \mathrm{OH}$, which would be subsequently converted to styrene; (2) the reaction of $\mathrm{H}^{\bullet}$ with $\mathrm{CH}_{3} \mathrm{OH}$ according to route $\mathrm{E}_{1}$ to generate $\mathrm{CH}_{3}{ }^{\circ}$, which would subsequently react with toluene to give $\mathrm{C}_{6} \mathrm{H}_{5} \mathrm{CH}_{2} \mathrm{CH}_{3}$; and (3) the reaction of $\mathrm{H} \cdot$ with $\mathrm{C}_{6} \mathrm{H}_{5} \mathrm{CH}=\mathrm{CH}_{2}$ following route $\mathrm{E}_{2}$ to give $\mathrm{C}_{6} \mathrm{H}_{5} \mathrm{CH}_{2} \mathrm{CH}_{3}$. Under an atmosphere of $\mathrm{CO}_{2}, \mathrm{H} \cdot$ would react with $\mathrm{CO}_{2}$ to form $\cdot \mathrm{COOH}$. The high bonding energy of the $\mathrm{C}-\mathrm{H}$ bond in formic acid (ca. $468 \mathrm{~kJ} / \mathrm{mol}$ ) indicates that the $\cdot \mathrm{COOH}$ radical could readily abstract a $\mathrm{H}$ atom from the methyl group of $\mathrm{CH}_{3} \mathrm{OH}$ to form $\mathrm{HCOOH}$ as an intermediate, which could decompose to give $\mathrm{H}_{2}$ and $\mathrm{CO}_{2}$ at the end of the reaction (Fig. 3(b)). It would be much more difficult for the $\cdot \mathrm{COOH}$ radical to obtain an $\mathrm{OH}$ moiety from $\mathrm{CH}_{3} \mathrm{OH}$ to form $\mathrm{H}_{2} \mathrm{CO}_{3}$ because of the low bonding energy of the $\mathrm{C}-\mathrm{OH}$ bond in $\mathrm{H}_{2} \mathrm{CO}_{3}$. $\mathrm{CH}_{3} \mathrm{OH}$ would therefore be more inclined to form styrene following route $\mathrm{S}$ because the reaction of $\mathrm{CH}_{3} \mathrm{OH}$ with - $\mathrm{COOH}$ would be relative facile and energetically favorable. The presence of $\mathrm{CO}_{2}$ would lead to a decrease in the concentration of $\mathrm{H}^{\bullet}$, which would lead to a further decrease in the production of $\mathrm{C}_{6} \mathrm{H}_{5} \mathrm{CH}_{2} \mathrm{CH}_{3}$ from the reaction between styrene and $\mathrm{H} \bullet$. Thus, the selectivity of the reaction for styrene would be increased. Pleasingly, the experimental results of this study were found to be consistent with the design strategy, as shown in Table 1, with the conversion of toluene decreasing slightly and the selectivity for styrene increasing from $17.4 \%$ to $59.4 \%$ when the reaction was conducted under $\mathrm{CO}_{2}$.

Table 1

Toluene side-chain alkylation data.

\begin{tabular}{|c|c|c|c|c|c|c|c|}
\hline Catalyst & $\begin{array}{c}\text { Conversion of } \\
\text { toluene (\%) }\end{array}$ & $\begin{array}{c}\text { Yield of } \\
\text { styrene (\%) }\end{array}$ & $\begin{array}{c}\text { Yield of EB } \\
(\%)\end{array}$ & $\begin{array}{c}\text { Selectivity of } \\
\text { styrene (\%) }\end{array}$ & $\begin{array}{l}\text { Conversion of } \\
\text { methanol (\%) }\end{array}$ & $\begin{array}{c}\text { Yield of } \\
\text { methane (\%) }\end{array}$ & $\begin{array}{c}\text { Yield of CO } \\
(\%)\end{array}$ \\
\hline $\bar{C}$ & 0.75 & 0.15 & 0.15 & - & - & - & - \\
\hline KX & 3.60 & 1.32 & 1.37 & - & 99.4 & 43.5 & 49.3 \\
\hline CsX & 16.60 & 2.89 & 12.67 & 17.4 & 98.2 & 34.2 & 48.2 \\
\hline $\mathrm{CsX}\left(\mathrm{CO}_{2}\right.$ atmosphere $)$ & 13.80 & 8.20 & 7.80 & 59.4 & - & - & - \\
\hline
\end{tabular}

$Y_{\mathrm{CO}}=N_{\mathrm{CO}, \text { out }} / N_{\mathrm{MeOH}, \text { in, }} Y_{\text {methane }}=N_{\text {methane, out }} / N_{\mathrm{MeOH}, \text { in, where }} N_{i}$ is calculated from the GC response signal (area of the FID or TCD peak) using the response factors for individual components and converted into mols. 


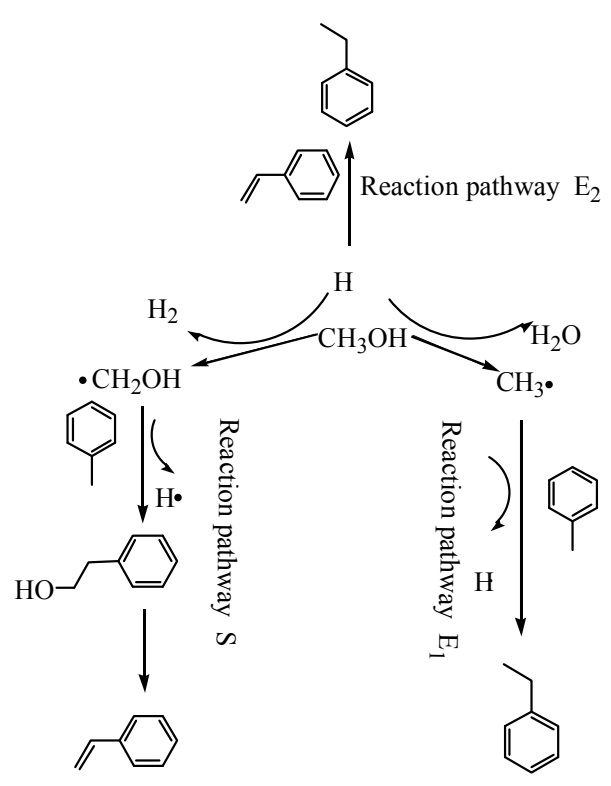

(a)

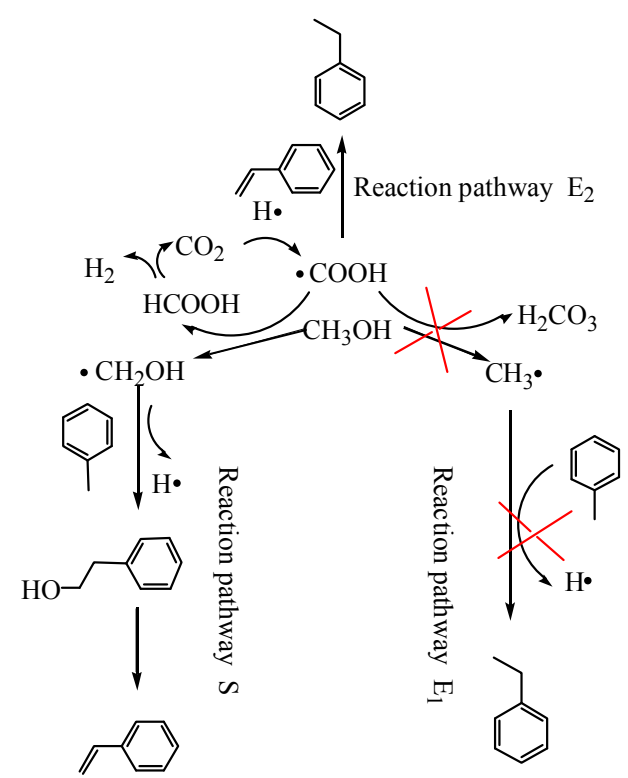

(b)

Fig. 3. (a) Reaction in atmosphere of $\mathrm{N}_{2}$; (b) Reaction in atmosphere of $\mathrm{CO}_{2}$.

\section{Conclusions}

The reaction mechanism of the side-chain alkylation of toluene has been fully elucidated using isotope tracing experiments, as well as investigative reactions between $p$-nitrotoluene and methanol. $\mathrm{H} / \mathrm{D}$ exchange reactions between $\mathrm{CD}_{3} \mathrm{OD}$ and $\mathrm{C}_{6} \mathrm{H}_{5} \mathrm{CH}_{3}$ provided experimental proof of the presence of free radicals in the reaction process. The results for the reaction between $p$-nitrotoluene and methanol further validated the idea that the side-chain alkylation of toluene proceeded via a free radical reaction mechanism. $\mathrm{Cs}^{+}$ions blocked $\mathrm{CH}_{3} \mathrm{OH}$ from going inside the $\beta$ cages, which consequently reduced the occurrence of side reaction. Furthermore, CsX was found to be more effective than KX for activating toluene towards free radicals, which was in agreement with the results of our experiments for the catalytic side-chain alkylation of toluene. In light of the strong interaction between $\mathrm{CO}_{2}$ and $\mathrm{H} \bullet$, the use of $\mathrm{CO}_{2}$ as carrier gas led to significant improvements in the selectivity for styrene.

\section{References}

[1] Yashima T, Sato K, Hayasaka T, Hara N. J Catal, 1972, 26: 303

[2] Itoh H, Miyamoto A, Murakami Y. J Catal, 1980, 64: 284

[3] Engelhardt J, Szanyi J, Valyon J. J Catal, 1987, 107: 296

[4] Itoh H, Hattori T, Suzuki K, Murakami Y. J Catal, 1983, 79: 21

[5] Borgna A, Sepúlveda J, Magni S, Apesteguía C. Stud Surf Sci Catal, 2000, 130: 2621

[6] Song L L, Li Z R, Zhang R Z, Zhao L F, Li W. Catal Commun, 2012, 19: 90

[7] Wieland W S, Davis R J, Garces J M. J Catal, 1998, 173: 490

[8] Hunger M, Schenk U, Burger B, Weitkamp J. Angew Chem Int Ed, 1997, 36: 2504

[9] Philippou A, Anderson M W.J Am Chem Soc, 1994, 116: 5774

\section{Graphical Abstract}

Chin. J. Catal., 2015, 36: 1726-1732 doi: 10.1016/S1872-2067(15)60896-8

Free radical mechanism investigation of the side-chain alkylation of toluene with methanol on basic zeolites $\mathrm{X}$

Huanhui Chen, Xiaoci Li, Guoqing Zhao, Hongbo Gu, Zhirong Zhu* Tongji University

$\mathrm{Cs}^{+}$complexes with the aromatic ring and attracts the electron, simultaneously, the anion on the framework of zeolite donates the electron to methyl group of toluene. The synergistic effect makes the radical much more stable.

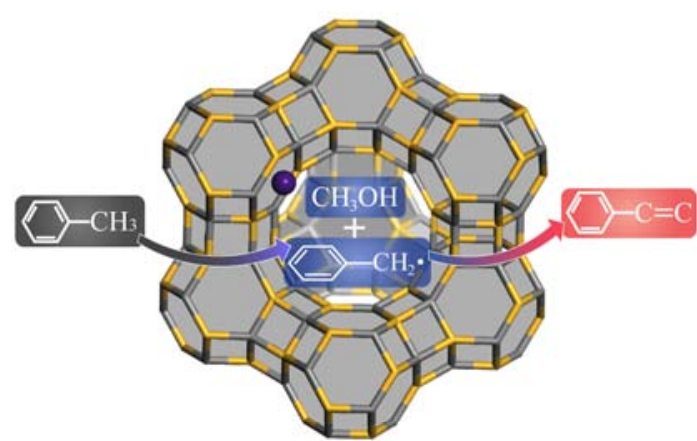


[10] Hunger M, Schenk U, Weitkamp J.J Mol Catal A, 1998, 134: 97

[11] Hunger M, Schenk U, Seiler M, Weitkamp J. J Mol Catal A, 2000, 156: 153

[12] Sidorenko Y N, Galich P N, Gutyrya V S, Il'in V G, Neimark I E. Dokl Akad Nauk SSSR, 1967, 173: 132

[13] Freeman J, Unland M. J Catal, 1978, 54: 183

[14] Rep M. [Ph.D. Dissertation]. University of Twente, Enschede, 2002, 172
[15] Su S J, Prairie M R, Renken A. Appl Catal A, 1992, 91: 131

[16] Toppi S, Thomas C, Sayag C, Brodzki D, Fajerwerg K, Le Peltier F, Travers C, Djéga-Mariadassou G. J Catal, 2005, 230: 255

[17] Jin T, Xia D H, Xiang Y Z, Zhou Y L. Petrol Sci Technol, 2009, 27: 1821

[18] Basler W D, Bein T. J Phys Chem, 1979, 83: 1233

[19] Viehe H G, Janousek Z, Merenyi R, Stella L. Acc Chem Res, 1985, 18: 148

\title{
碱性X分子篮催化甲苯与甲醇侧链烷基化自由基机理研究
}

\author{
陈焕辉，李孝慈，赵国庆，谷红波，朱志荣*
}

同济大学化学系, 上海200092

摘要: 苯乙烯是重要的工业原料, 年消耗量约 3000 万吨. 传统工艺中, 苯乙烯由乙苯催化脱氢得到. 由于传统工艺高能耗, 高污染, 甲苯与甲醇侧链烷基化合成苯乙烯引起了人们广泛关注, 但是目前该路线进入工业化还有很多问题需要解决, 甚至催化机理仍不 明确. 本文对甲苯侧链烷基化机理及提高反应选择性等方面进行了研究.

采用离子交换法制备 $\mathrm{CsX}$ 分子篮, 在固定床反应器上进行甲苯与気代甲醇的同位素示踪实验和硝基甲苯的侧链烷基化实验, 结合量子计算明确反应机理. 采用IGA-002系统测定甲醇在 CsX, KX和 NaX上的等温吸附线, 考察甲醇在分子笁不同笼结构中的 吸附情况. 将氝代甲苯与甲苯在 $\mathrm{CsX}, \mathrm{KX}$ 和活性炭催化下进行氢氝交换实验, 检验自由基在不同催化剂上的稳定性. 以 $\mathrm{CO}_{2}$ 为载 气进行甲苯与甲醇侧链烷基化实验, 考察 $\mathrm{CO}_{2}$ 对反应的影响.

甲苯与氞代甲醇进行侧链烷基化反应时, 大多数気出现在甲苯上, 仅少数気存在于苯乙烯及乙苯上, 表明甲苯氢与甲醇的甲 基気进行了氢気交换. 量子化学计算表明, 甲苯与甲醇的氢気交换沿自由基路径的能垒远小于沿离子路径的. 氛代实验和量子计 算结果表明, 甲苯侧链烷基化过程中存在自由基, 但并不能证明侧链烷基化是自由基反应. 为了验证甲苯侧链烷基化反应是否为 自由基机理, 以4-硝基甲苯 $\left(\mathrm{NO}_{2}-\mathrm{Ph}-\mathrm{CH}_{3}\right)$ 代替甲苯与甲醇进行侧链烷基化反应. 硝基是强吸电子基团, 能稳定芐基负离子, 如果 甲苯侧链烷基化是离子反应，硝基甲苯侧链烷基化产物收率会升高. 另外，硝基又能与活泼自由基生成稳定自由基，若反应为自 由基机理, 则硝基甲苯不发生侧链烷基化反应. 分析结果表明, 反应液中不存在侧链烷基化产物, 确定了甲苯侧链烷基化反应为 自由基机理, 而不是离子机理.

热力学上甲醇更容易进行生成 $\mathrm{CO}$ 和 $\mathrm{H}_{2}$ 等的副反应, 从而减少 $\mathrm{CH}_{3}{ }^{\bullet}$ 与 $\mathrm{H}^{\bullet}$ 碰撞甲醇的几率. 甲醇等温吸附线显示甲醇在 $\mathrm{NaX}$ 和 $\mathrm{KX}$ 上的吸附容量相近且远大于 $\mathrm{CsX}$ 上的, 表明 $\mathrm{Cs}^{+}$阻碍了甲醇进入X分子笁的 $\beta$-笼. 由于甲苯不能进入 $\beta$-笼, $\mathrm{NaX}$ 和 $\mathrm{KX}$ 的 $\beta$-笼内甲 醇与甲基自由基接触发生副反应. $\mathrm{CsX}$ 催化时 $\mathrm{Cs}^{+}$阻碍甲醇进入 $\beta$-笼而抑制了副反应的发生, 提高了甲醇利用率.

甲苯与氞代甲苯在 $\mathrm{CsX}, \mathrm{KX}$ 和活性炭上进行氢気交换, 反应物用 GC-MS分析. 结果表明, 在 $\mathrm{CsX}$ 上氢気交换进行得更彻底, 在 活性炭上几乎没有氢氛交换. X分子笁活化甲苯为自由基的效果优于活性炭,这可能是推拉效应造成的. 当甲苯进入分子笁后, Lewis酸性阳离子与苯环络合并吸引电子, 催化剂阴离子骨架与甲苯的甲基作用并供给电子, 推电子与吸电子共同作用使甲苯更 容易生成苄基自由基, 并使其更稳定. CsX对甲苯的活化作用强于 $\mathrm{KX}$, 表明 $\mathrm{CsX}$ 的酸碱搭配更有助于甲苯生成自由基. 这也是 $\mathrm{CsX}$ 催化甲苯与甲醇侧链烷基化效果优于KX的原因.

以 $\mathrm{CO}_{2}$ 替代 $\mathrm{N}_{2}$ 作为载气能显著提高苯乙烯的选择性, 这是由于 $\mathrm{CO}_{2}$ 的存在降低了 $\mathrm{H}^{*}$ 和 $\mathrm{CH}_{3}{ }^{*}$ 的浓度, 提高了 ${ }^{\circ} \mathrm{CH}_{2} \mathrm{OH}$ 的浓度. ${ }^{\circ} \mathrm{CH}_{2} \mathrm{OH}$ 与甲苯生成苯乙烯, $\mathrm{H}^{*}$ 的减少降低了苯乙烯加氢生成乙苯.

关键词: 甲苯; 侧链烷基化; 自由基机理；X分子篮; 苯乙烯; 同位素示踪

收稿日期: 2015-03-27. 接受日期：2015-05-18. 出版日期: 2015-10-20.

*通讯联系人. 电话：(021)65982563; 传真：(021)65982563; 电子信箱：zhuzhirong@tongji.edu.cn

基金来源：国家自然科学基金(51174277); 上海市重点基础研究(11JC1412500).

本文的英文电子版由Elsevier出版社在ScienceDirect上出版(http://www.sciencedirect.com/science/journal/18722067). 